\title{
Canopy bridges as road overpasses for wildlife in urban fragmented landscapes
}

\author{
Fernanda Zimmermann Teixeira ${ }^{1,3,4}$, Rodrigo Cambará Printes ${ }^{2,3}$, \\ João Cláudio Godoy Fagundes ${ }^{3}$, André Chein Alonso ${ }^{3}$ \& Andreas Kindel ${ }^{1}$ \\ ${ }^{1}$ Programa de Pós-graduação em Ecologia, Universidade Federal do Rio Grande do Sul - UFRGS, \\ Av. Bento Gonçalves, 9500, Bloco IV, prédio 43411, sala 209, CP 15007, CEP 91501-970, \\ Porto Alegre, RS, Brasil. http://www.ecologia.ufrgs.br/ppgeco/ \\ ${ }^{2}$ Laboratório de Gestão Ambiental e Negociação de Conflitos, Universidade Estadual do Rio Grande do \\ Sul - UFRGS, Campus II, Rua Assis Brasil, 842, Centro, São Francisco de Paula, RS, Brasil \\ ${ }^{3}$ Núcleo de Extensão Macacos Urbanos, Universidade Federal do Rio Grande do Sul - UFRGS, \\ Av. Bento Gonçalves, 9500, Bloco IV, anexo prédio 43411, sala 21, CP 15007, \\ CEP 91501-970, Porto Alegre, RS, Brasil. http://www.ufrgs.br/macacosurbanos \\ ${ }^{4}$ Corresponding author: Fernanda Zimmermann Teixeira, e-mail: fernandazteixeira@gmail.com
}

TEIXEIRA, F.Z., PRINTES, R.C., FAGUNDES, J.C.G., ALONSO, A.C. \& KINDEL, A. Canopy bridges as road overpasses for wildlife in urban fragmented landscapes. Biota Neotrop. 13(1): http://www.biotaneotropica. org.br/v13n1/en/abstract?article+bn02713012013

\begin{abstract}
The effects of habitat fragmentation and deforestation are exacerbated by some elements, such as roads and power lines, which may become filters or barriers to wildlife movements. In order to mitigate mortality and restore connectivity, wildlife passages are being constructed as linear corridors. The installation of these mitigation measures must be followed by systematic monitoring, in order to evaluate their use and effectiveness, to assist in their management, and to convince stakeholders of their value. In this paper we present the results of a monitoring study of the use of rope overpasses developed near a protected area in Porto Alegre, southern Brazil. The canopy bridges were installed by the Urban Monkeys Program in places where electric hazards and road-kills of brown howler monkeys (Alouatta guariba clamitans Cabrera, 1940) were recorded. Camera traps were installed at each bridge, and local people were selected and trained to monitor overpass use over 15 months, from August 2008 to October 2009. Three species were recorded using canopy bridges: brown howler monkey (Alouatta guariba clamitans Cabrera, 1940), white-eared opossum (Didelphis albiventris Lund, 1840) and porcupine (Sphiggurus villosus Cuvier, 1823). Rope bridges with the highest number of species recorded had more forest cover and lower urban area around them than overpasses little used. Our results indicate that overpasses, in Porto Alegre, work as a linear corridor between forest remnants, although the outcomes for individual survival, group persistence, population demography or gene flow have not been measured. Furthermore, canopy bridges may be important to mitigate the impact of roads and power lines on wildlife, but electric cables also need to be completely isolated when present, to warrant animals' physical integrity.
\end{abstract}

Keywords: road, power lines, primates, mitigation, wildlife passage, rope bridge.

TEIXEIRA, F.Z., PRINTES, R.C., FAGUNDES, J.C.G., ALONSO, A.C. \& KINDEL, A. Pontes de corda como passagens para animais silvestres em paisagens urbanas fragmentadas. Biota Neotrop. 13(1): http://www. biotaneotropica.org.br/v13n1/pt/abstract?article+bn02713012013

Resumo: Os efeitos do desmatamento e da fragmentação de hábitats são exacerbados por elementos como rodovias e redes elétricas, que podem atuar como filtros ou barreiras aos movimentos da vida silvestre. Com o objetivo de mitigar a mortalidade e restaurar a conectividade, passagens de fauna têm sido construídas como corredores lineares. A instalação dessas estruturas deve ser seguida de monitoramento sistemático, visando à avaliação de seu uso e efetividade e a geração de informações para seu manejo e para convencer os tomadores de decisão sobre seu valor. Neste artigo, apresentamos os resultados do monitoramento do uso de seis pontes de corda, realizado durante 15 meses, entre agosto de 2008 e outubro de 2009, nas imediações da Reserva Biológica do Lami José Lutzenberger, em Porto Alegre, Brasil. As pontes de dossel foram instaladas pelo Núcleo de Extensão Macacos Urbanos em locais com registros de atropelamentos e choques elétricos de bugios-ruivos (Alouatta guariba clamitans Cabrera, 1940). Instalamos armadilhas fotográficas em cada ponte e selecionamos moradores locais para registrarem seu uso. Três espécies foram registradas usando as pontes de corda: o bugio-ruivo (Alouatta guariba clamitans Cabrera, 1940), o gambá-de-orelha-branca (Didelphis albiventris Lund, 1840) e o ouriçocacheiro (Sphiggurus villosus Cuvier, 1823). As pontes de corda mais usadas por maior número de espécies são aquelas situadas nas áreas de maior cobertura florestal e menor área urbanizada, em relação às pontes menos usadas pelas espécies. Nossos resultados indicam que as pontes de corda funcionam como um corredor linear entre os remanescentes florestais, embora não tenhamos avaliado os efeitos das pontes sobre a sobrevivência dos indivíduos, persistência e demografia dos grupos e fluxo gênico na população. Além disso, as pontes podem ser usadas para mitigar o impacto de redes elétricas e rodovias sobre a mortalidade, mas os cabos elétricos também devem ser completamente isolados quando presentes.

Palavras-chave: rodovias, redes elétricas, primatas, mitigação, passagens de fauna, pontes de corda. 


\section{Introduction}

Tropical and subtropical forests are threatened by deforestation and fragmentation. These processes reduce the extension of forests and transform them in small and isolated fragments. In extreme cases, the creation of isolated patches could result in the interruption of wildlife movements between local populations (Valladares-Padua et al. 1995). Habitat fragmentation creates small and isolated subpopulations, rising extinction probabilities due to demographic, environmental, and genetic forces (Frankham et al. 2004). In urban areas, these effects are exacerbated by elements of urban matrix, such as roads and power lines, which may become filters or barriers to wildlife movements. Nowadays, road-kills are considered the major direct human cause of mortality of terrestrial animals worldwide (Forman \& Alexander 1998), and wildlife electrocutions have been documented as having an important impact on some animal populations in urban landscapes (Lehman et al. 2007, Lokschin et al. 2007).

Some alternatives are being developed to mitigate mortality and restore landscape connectivity, such as the construction of wildlife passages as linear corridors (Goosem et al. 2006, Laurence et al. 2009). These connection structures are site-specific movement corridors constructed over or bellow roads (Clevenger \& Waltho 2003). Underpasses and green bridges over roads are being widely built, and their use has been documented in different places around the world (Taylor \& Goldingay 2010, Beckmann et al. 2010). On the other hand, canopy rope bridges are a recent innovation that aims to provide functional connectivity for target arboreal species (Taylor \& Goldingay 2010) where canopy maintenance is infeasible (Laurence et al. 2009). Although the first canopy bridge was installed in 1963 in the United States (Weston 2003), only recently these overpass structures have been disseminated and installed in places like Australia (Goosem et al. 2006), Belize (Lyon \& Horwich 1996), and Brazil (Valladares-Padua et al. 1995, Lokschin et al. 2007).

The installation of these mitigation measures must be followed by systematic monitoring of their use, in order to evaluate the effectiveness of the passages, to assist in their management, and to convince stakeholders of their value (Malo et al. 2006, Cuarón 1995). Some efforts have been expended in monitoring passages, but the available information usually derives from a few intensive studies carried out in relatively few places (Forman et al. 2003). Although the monitoring of wildlife underpasses has become more common recently (Beckmann et al. 2010), only in Australia, to our knowledge, monitoring studies have been developed on the use of rope overpasses by arboreal mammals (Goosem et al. 2006, Soanes \& van der Ree 2009, Weston et al. 2011). The use of wildlife passages is a precondition and first approximation to the effectiveness of these measures, even though it is not a direct measure of effectiveness, which should be demonstrated by indicators such as survival rates or gene flow, variables relatively difficult to obtain.

In order to generate information to the management of canopy bridges, we present here the results of a monitoring study of the use of rope overpasses developed near a protected area in Porto Alegre, southern Brazil. The Urban Monkeys Program (www.ufrgs.br/ macacosurbanos) has been recording electric hazards and road-kills of brown howler monkeys (Alouatta guariba clamitans Cabrera, 1940) in that region since 1999 (Printes 1999), and some mitigation measures have been implemented to reduce mortality of howlers and birds (i.e Asio clamator Vieillot, 1808 and Chauna torquata Oken, 1816) due to these causes. Power lines were insulated to avoid wildlife electrocutions, and rope overpasses were installed to stimulate the crossing of howlers between forest patches (Lokschin et al. 2007).

Our goal in this study was to identify which species use the rope bridges and to evaluate if their use is related with the landscape composition around each rope bridge. To obtain data on overpass use we installed camera traps and selected and trained local people to monitor each bridge.

\section{Materials and Methods}

\section{Study area}

This study was conducted at the Lami district, in the Porto Alegre municipality, southern Brazil. With a 1.4 million population (Instituto... 2010), around 10\% of the municipality is still covered by semi-deciduous seasonal forests (Menegat et al. 1998), one of the forest typologies of Atlantic rainforest in southern Brazil (OliveiraFilho \& Fontes et al. 2000). The José Lutzenberger-Lami Biological Reserve (180 ha) is located in the southernmost region of Porto Alegre, and its surroundings are composed of a heterogeneous matrix of wetlands, forest patches, and native and planted grasslands (see Results). The urban area of the Lami district is also located near the reserve, with $0.39 \%$ of Porto Alegre's inhabitants (Instituto... 2010), characterized by houses with native trees still remaining in their yards. Due to the small size of the reserve, animals transit between the reserve and its surrounding area. Since 1999, the Urban Monkeys Program has been documenting howler monkey mutilations and deaths caused by electric hazards in Lami, due to aerial power lines used by them for moving between forest patches and resource trees (Printes 1999).

\section{The canopy bridges}

The six rope bridges monitored in this study are distributed in the Lami district, in the buffer zone of the José Lutzenberger-Lami Biological Reserve. Each rope bridge is similar to a horizontal 'ship' ladder (Lokschin et al. 2007), and the length of each bridge varies with the width of the road. The bridge is constructed with four $12 \mathrm{~mm}$ parallel ropes, the two external ones always straight and approximately $50 \mathrm{~cm}$ from each other, while the two internal ones are interlaced forming an " $\mathrm{X}$ " between each step. The " $\mathrm{X}$ " is fixed with a plastic clamp. The ladder steps are formed by rubber hose with a diameter of approximately $7 \mathrm{~cm}$ and are separated from each other by approximately $80 \mathrm{~cm}$ (Figures 1 and 2). Each canopy bridge costs near US\$100.00, not considering the material needed for fixation and installation. They were installed over roads in critical points, based on documented cases of electrocuted and road-killed animals and on known crossing attempts by howlers. These are dirty and paved roads with one or two narrow lanes without central median. The installation of rope overpasses was carried out together with the insulation of electric cables where the majority of accidents occurred (Lokschin et al. 2007). The rope bridges were installed as an effort of the Urban Monkeys Program for howler conservation, with collaborative support from the municipal environmental agency and electric energy company. Three bridges were installed in 2001 and 2003, and the other three were installed in 2006, but their use was not systematically monitored until 2008. Rope bridges were designed targeting the brown howler monkey (Alouatta guariba clamitans Cabrera, 1940), a species vulnerable to extinction in the Rio Grande do Sul state (Marques 2003), often electrocuted, road-killed, and attacked by dogs in the Porto Alegre municipality.

\section{Data collection and analysis}

Each of the six rope bridges was monitored using a camera trap installed during seven days per month to record the different arboreal species using it. The rope bridges were monitored over 15 months, from August 2008 to October 2009, except for one of them (the Samir bridge) where the cameras were installed only over the first six months due to access limitations to the area (Table 1). We used Tigrinus 

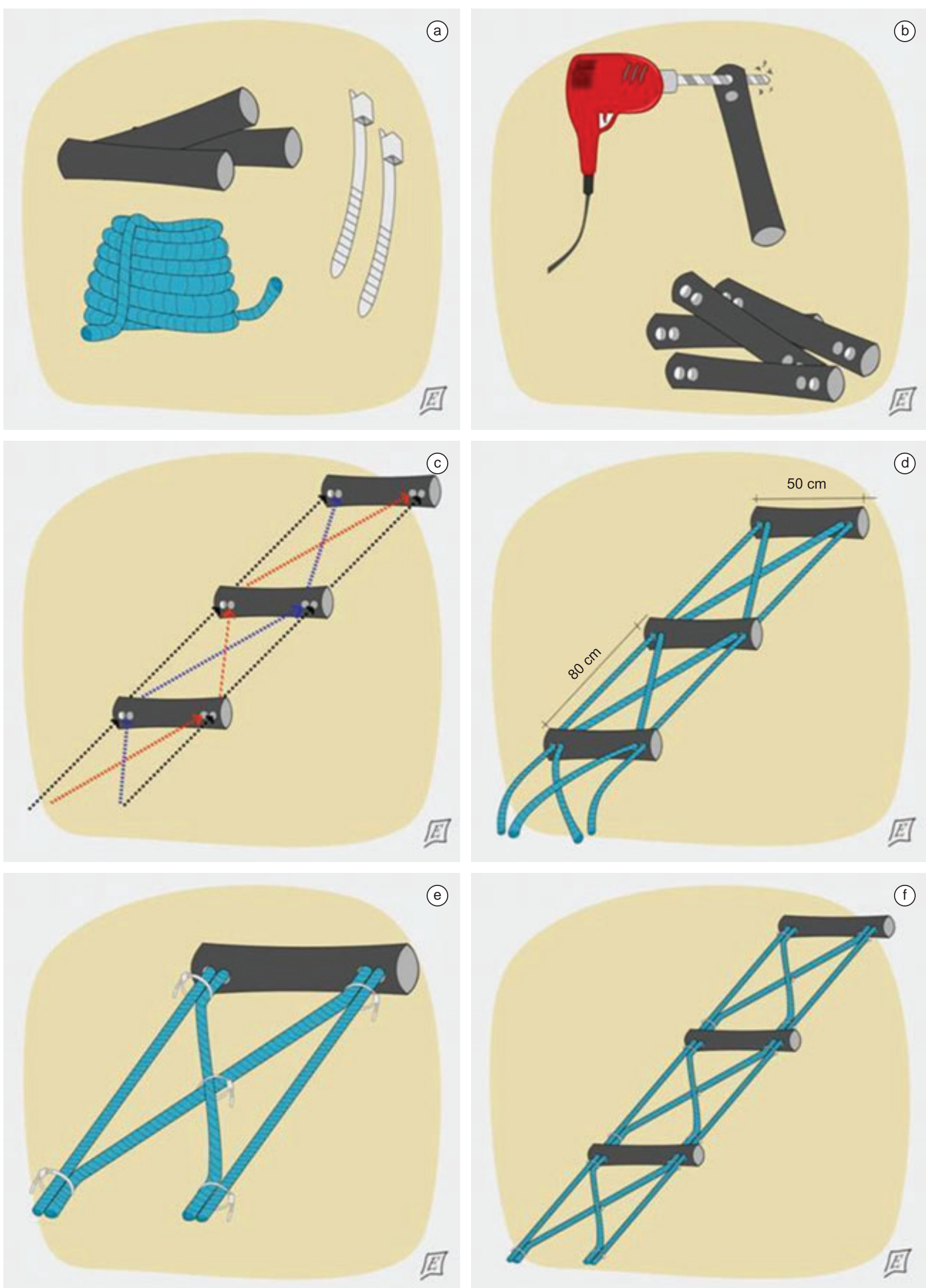

(e)

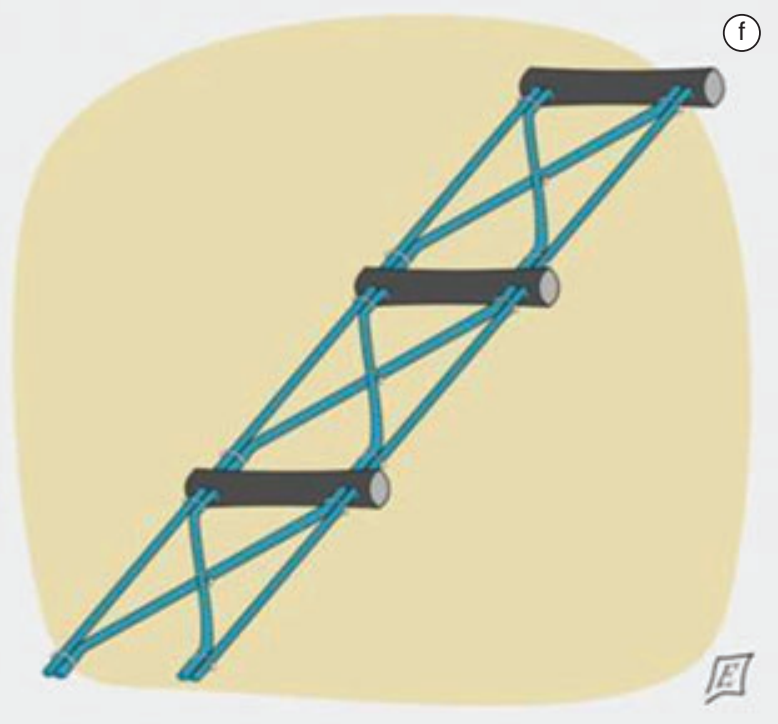

Figure 1. Construction of rope overpass with four $12 \mathrm{~mm}$ ropes interlaced and rubber hose to form ladder steps. Author: Elisandro Oliveira dos Santos. 
Table 1. Location of canopy bridges and sample effort of camera traps (number of days) during monitoring.

\begin{tabular}{ccc}
\hline Rope overpass & UTM coordinates 22J datum SAD69 & Camera trap sample effort (days) \\
\hline Pontal (1) & $490898 / 6654835$ & 119 \\
Samir (2) & $491457 / 6654600$ & 33 \\
Tonho (3) & $491575 / 6654731$ & 152 \\
Fupala (4) & $491712 / 6654832$ & 148 \\
Espigão (5) & $492198 / 6654789$ & 127 \\
Pituca (6) & $492365 / 6654454$ & 110 \\
\hline
\end{tabular}

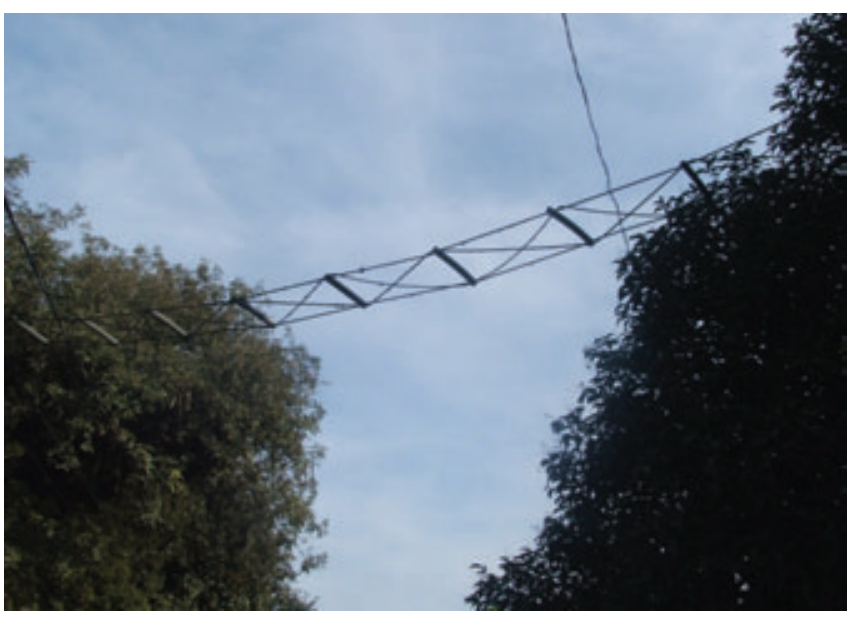

Figure 2. Rope overpass constructed with four $12 \mathrm{~mm}$ ropes interlaced and rubber hose to form ladder steps in Lami district, Porto Alegre municipality, southern Brazil. Photo: João Cláudio Godoy Fagundes.

(www.tigrinus.com.br) analogical camera traps, and each camera operated until all 36 photos were shot. Additionally, we involved the local community in the monitoring by choosing neighbors to record overpass use. Each local observer should record the species, number of individuals, date and sighting time of animals they saw crossing the bridges. Camera and local community monitoring were carried out during the same period.

In order to relate the use of the rope bridges to the surrounding land use/cover, we evaluated the landscape composition in a buffer with an $80 \mathrm{~m}$ radius $\left(2000 \mathrm{~m}^{2}\right)$ around each rope bridge. This buffer size was selected to avoid superposition of buffers due to the proximity of the bridges. We recorded the percentage of each class of land use/cover within each buffer, according to Porto Alegre's Environmental Diagnostic (Hasenack 2008). The analysis was performed with the Idrisi Andes software (Eastman 2003).

The study design was planned aiming to manage real situations, thus each bridge location was chosen due to howler electrocution history and they are near to each other, so there is not independence between sample units. Besides that, the number of rope bridges is too low to perform an adequate statistical analysis. The best alternative, in this context, was a descriptive analysis of the data.

\section{Results}

During the 15 months of monitoring we recorded three native mammal species using rope bridges: brown howler monkey (Alouatta guariba clamitans Cabrera, 1940), white-eared opossum (Didelphis albiventris Lund, 1840), and porcupine (Sphiggurus villosus Cuvier, 1823). All three species were photographed by the infrared-triggered camera (Figure 3), but intensive false photograph shooting (especially due to vehicles passing under the rope bridge) jeopardized the estimates of use frequency. Whereas local people recorded only brown howler monkeys and white-eared opossums using the bridges (Table 2), they documented by photography and videos the use of two overpasses by howlers that were not recorded by camera traps. Although local people recorded the use of howlers in more bridges and more often than camera traps, they recorded only two crossings of opossums and none of porcupines.

We identified four classes of landscape cover neighboring the rope bridges: arboreal, urban, open vegetation and water (Table 3). The only rope bridge that was used by the three species (Fupala) was the one with the highest forest cover (67.26\%) and also the lowest urban area (12.91\%), although it was located in the center of the urban region of the Lami district (Figure 4). In addition, the bridge with two species recorded (Espigão) had the second lowest urban cover (36.53\%) and the highest open vegetation cover (43.36\%). On the other hand, the two overpasses with no records of use by any species had higher values of urban cover (Samir and Tonho).

\section{Discussion}

Considering the 19 mammal species that occur in José Lutzenberger-Lami Biological Reserve (Printes 2002) as the species occurring in the Lami district, all medium-sized mammals with arboreal habits were recorded crossing overpasses. This fact indicates that overpasses in the Lami district are a functional canopy connection for these species, working as a linear corridor and restoring connectivity between forest remnants. However, to detect the effectiveness of rope bridges in conservation management, besides identifying the use of overpasses, it is necessary to consider if barrier effects and mortality are reduced and if populations are benefited (Huijser et al. 2007, Taylor \& Goldingay 2010). van der Ree et al. (2007) showed that most studies on wildlife passages show that mitigation can be considered successful at the level of the individual animals, but the implications on population persistence should also be monitored.

There are differences between our canopy bridge model and the pole bridge installed for the black lion tamarin (Leontopithecus chrysopygus Mikan, 1823) in the São Paulo state, Brazil (Valladares-Padua 1995), and also between our overpass and the canopy bridges installed in Australia (Soanes \& van der Ree 2009, Weston et al. 2011). The bridge in São Paulo is constructed using round wooden poles and is installed at a height of $6 \mathrm{~m}$ over the road, while in Australia there are two models of canopy overpass - a rope ladder (with the steps also formed by rope) and a rope tunnel. The pole bridge in São Paulo is narrower than the rope bridges, making it difficult for some animals to cross, but it is also less instable than the ropes, what can increase its attractiveness. In Australia, the rope tunnels were built in order to provide protection for crossing animals from aerial predators, but most times animals crossed using the top surface of the rope tunnel. All these different types of overpasses were 

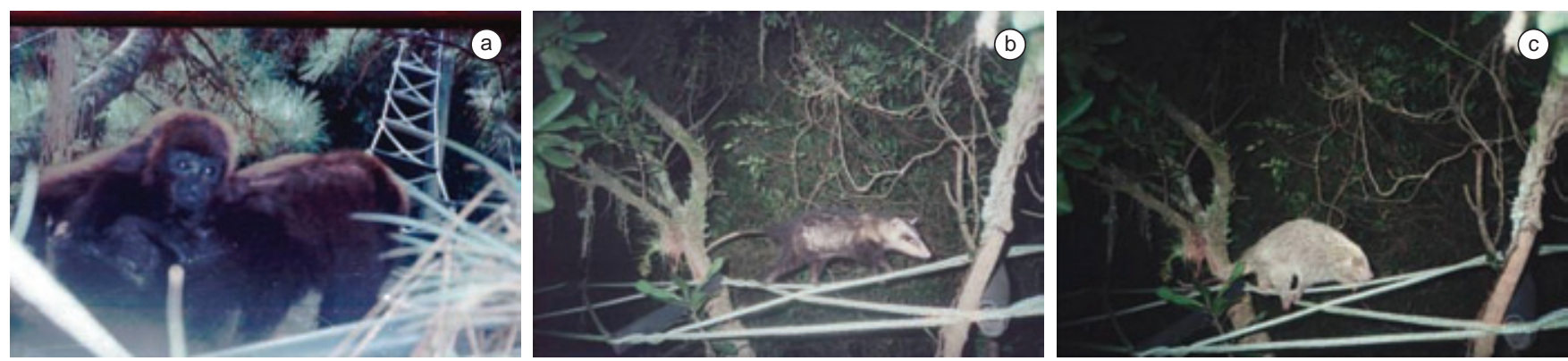

Figure 3. Species recorded using canopy bridges by camera traps. a) Brown-howler-monkey (Alouatta guariba clamitans Cabrera, 1940). b) White-earedopossum (Didelphis albiventris Lund, 1840). c) Porcupine (Sphiggurus villosus Cuvier, 1823).

Table 2. Wildlife use of canopy rope bridges recorded during monitoring (1=bridge use recorded, 0=bridge use not recorded).

\begin{tabular}{|c|c|c|c|c|c|c|}
\hline \multirow{2}{*}{ Rope overpass } & \multicolumn{2}{|c|}{ Alouatta guariba clamitans } & \multicolumn{2}{|c|}{ Sphiggurus villosus } & \multicolumn{2}{|c|}{ Didelphis albiventris } \\
\hline & CT & LP & CT & LP & CT & LP \\
\hline Pontal (1) & 1 & 1 & 0 & 0 & 0 & 0 \\
\hline Samir (2) & 0 & 0 & 0 & 0 & 0 & 0 \\
\hline Tonho (3) & 0 & 0 & 0 & 0 & 0 & 0 \\
\hline Fupala (4) & 0 & 1 & 1 & 0 & 1 & 1 \\
\hline Espigão (5) & 0 & 1 & 1 & 0 & 0 & 0 \\
\hline Pituca (6) & 0 & 1 & 0 & 0 & 0 & 0 \\
\hline
\end{tabular}

$\mathrm{CT}$ = camera trap; $\mathrm{LP}=$ local people.

Table 3. Landscape composition within each buffer $\left(2000 \mathrm{~m}^{2}\right)$ around each rope overpass installed in Lami District, Porto Alegre, RS, Brazil.

\begin{tabular}{lcccc}
\hline \multirow{2}{*}{ Rope overpass } & \multicolumn{4}{c}{ Type of landscape cover (\%) } \\
\cline { 2 - 5 } & Arboreal & Open vegetation & Water & Urban \\
\hline Pontal (1) & 54.87 & 7.73 & 0 & 37.4 \\
Samir (2) & 0 & 11.49 & 26.75 & 61.77 \\
Tonho (3) & 23.14 & 0 & 0 & 76.86 \\
Fupala (4) & 67.26 & 19.83 & 0 & 12.91 \\
Espigão (5) & 20.12 & 43.36 & 0 & 36.53 \\
Pituca (6) & 0 & 19.33 & 0 & 80.67 \\
\hline
\end{tabular}

constructed for different target species, which makes it difficult to compare their use and effectiveness. When building a rope or pole overpass, the size and weight of the target species must be considered. Also, to increase the probability of a species using a canopy bridge, it is important to consider the distance between animal limbs and the way the species moves. The effects of variables related to the use of mitigation structures are likely to be species or species-group specific (van der Ree et al. 2007).

The information obtained by local people on overpass use by photography and video confirm that this kind of monitoring can be reliable, increasing the amount of data obtained and having an educational impact. Local people collected some important information about howlers' crossings and activities (such as the presence of infants, injured individuals, or some specific native fruit consumed), but there were only two records of use by other species. This difference may be explained by howlers' larger size and behavior, and by their diurnal habits, while the other two species have small body size, and have nocturnal and solitary habits. The results obtained with the monitoring by local people show the usefulness of involving the community in conservation actions, but should be applied carefully, since there are differences in observational effort and detectability among different local people. The collaboration of local community has educative and interpretive value and is vital for the successful implementation of conservation activities (Lokschin et al. 2007, Weston et al. 2011).

Although all rope bridges have urban areas around them (which is the origin of accidents such as electrocutions, road-kills and dog attacks), the two bridges with the lowest urban areas were the ones where other species besides howlers were recorded. Two overpasses did not have any forest cover within the buffer, but in one of them local people photographed howlers using the bridge. The use of a bridge to cross between areas with no forest cover may be explained by the low resolution of the land use map available, which does not allow the individualization of garden and orchard trees, an important matrix element for fauna in this region. Unfortunately, our small sample size does not allow us to draw conclusions about the importance of particular landscape features for wildlife.

An important question that remains to be answered is if animal movement trough the rope bridge is a diurnal movement providing an extension of home range, or if the canopy bridges are used by animals for dispersing. Considering information obtained with local people about howler monkeys' use of the passages, it appears that the same howler group uses the overpass over time, indicating that it plays a role in widening howlers' home range. Goosem et al. (2008) and Weston et al. (2011), while monitoring canopy bridge use by possums in Australia, did not find any evidence that the individuals remained on the visited side, as all the crossing photographs also show the animal returning to the side of origin within a few hours of crossing. Canopy bridges may allow animals to access resources located on the other side of the road, what may increase the probability of individual survival. However, we did not test survivorship of individuals and we also did not test if there was a decrease in mortality due to wildlife-vehicle collisions or electrocutions. Taylor \& Goldingay (2012) when analyzing population viability of squirrel gliders (Petaurus norfolcensis Kerr, 1792) found that facilitating 


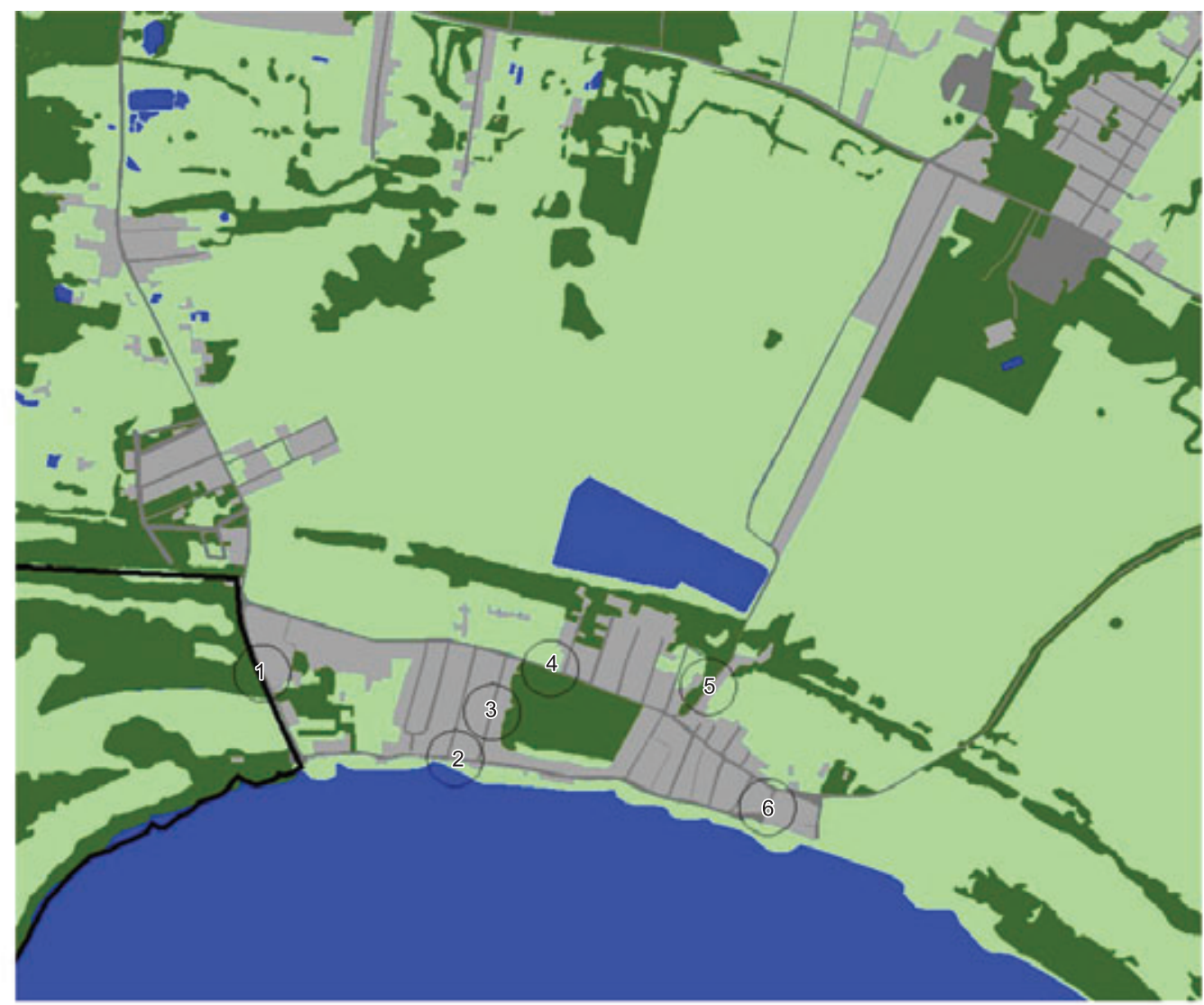<smiles></smiles>

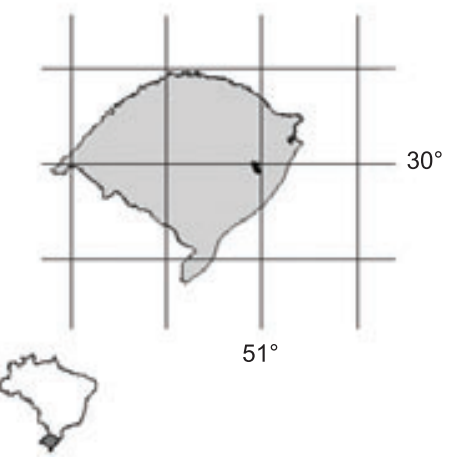

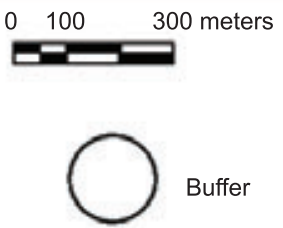

Rope bridges

1 Pontal

2 Tonho

3 Samir

4 Fupala

5 Espigão

6 Pituca

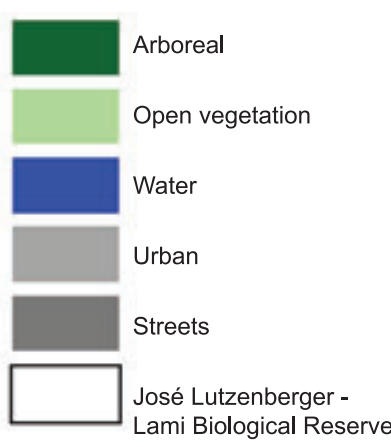

Figure 4. Landscape composition within buffers of $2000 \mathrm{~m}^{2}$ around each rope bridge installed in Lami District, Porto Alegre, RS, Brazil.

inter-patch movement by installing canopy bridges and wooden poles for gliding was the key to diminish extinction probabilities.

Studies published on the use and effectiveness of canopy bridges as mitigation measures for the impact of power lines and roads on wildlife are still scarce, although they are critical for evaluating the success of mitigation implemented. In Australia there are already long-term monitoring of rope bridges following overpass construction (Goosem et al. 2008, Weston et al. 2011), while in Brazil this is a novel conservation concern. Other methods can also be used to monitor rope overpass use: Weston et al. (2011) used direct observation, collection of fecal pellets, and hair sampling, with varied species detection.

\section{Conclusions}

This study demonstrates the functionality of rope overpasses in southern Brazil for all arboreal mammals present in the area. Our results are important to demonstrate the use of these structures by all target species, although the importance of these movements for gene flow and population persistence remains to be evaluated. Bridges are very important to keep connectivity between fragments and can mitigate the impact of power lines over wildlife, but electric cables, commonly recognized by howlers as an alternative route for canopy gap crossing, also need to be completely isolated when present, to warrant animals' physical integrity. 


\section{Aknowledgements}

We thank the community of Lami District that was involved in data collection, Núcleo de Fauna/SMAM for collaborating in the management of electrocuted howlers, and BIC/UFRGS (project 12944) and Fundação O Boticário de Proteção à Natureza (project 0779_20081) for financial support. We thank all members of Núcleo de Extensão Macacos Urbanos/UFRGS for the contributions in this study, especially Elisandro Oliveira dos Santos for drawing the canopy bridge model for this manuscript. We also thank the two anonymous reviewers for improvements in an early version of the manuscript.

\section{References}

BECKMANN, J.O., CLEVENGER, A.P., HUIJSER, M.P. \& HILTY, J.A. 2010. Safe passages - Highways, wildlife, and habitat connectivity. Island Press, 396p.

CLEVENGER, A.P. \& WALTHO, N. 2003. Long-term, year-round monitoring of wildlife crossing structures and the importance of temporal and spatial variability in performance studies. In Proceedings of the 2007 International Conference on Ecology and Transportation (C.L. Irwin, D. Nelson \& K.P. McDermott, eds.). Center for Transportation and the Environment, North Carolina State University, p.293-302.

CUARÓN, A.D. 1995. Pole bridges to avoid primate kills: a sequel do Valladares-Padua et al. Neotrop Primates 3(3):74-75.

EASTMAN, J.R. 2003. IDRISI Kilimanjaro - Guide to GIS and Image Processing. Clark University, 306p.

FORMAN, R.T.T. \& ALEXANDER, L.E. 1998. Roads and their major ecological effects. Annu. Rev. Ecol. Syst. 29:207-31. http://dx.doi. org/10.1146/annurev.ecolsys.29.1.207

FORMAN, R.T.T., SPERLING, D., BISSONETTE, J.A., CLEVENGER, A.P., CUTSHALL, C.D., DALE, V.H., FAHRIG, L., FRANCE, R., GOLDMAN, C.R., HEANUE, K., JONES, J.A., SWANSON, F.J., TURRENTINE, T. \& WINTER, T.C. 2003. Road Ecology: Science and Solutions. Washington, Island Press, 481p.

FRANKHAM, R., BALLOU, J.D. \& BRICOE, D.A. 2004. A Primer of Conservation Genetics. Cambridge University Press, 236p. http://dx.doi. org/10.1017/CBO9780511817359

GOOSEM, M., WESTON, N. \& BHUSHNELL, S. 2006. Effectiveness of rope bridge arboreal overpasses and faunal underpasses in providing connectivity for rainforest fauna. In Proceedings of the 2005 International Conference on Ecology and Transportation (C.L. Irwin, D. Nelson \& K.P. McDermott, eds.). Center for Transportation and the Environment, North Carolina State University, p.304-316.

GOOSEM, M., WILSON, R., WESTON, N. \& COHEN, M. 2008. Highway overpass evaluation of effectiveness: Kuranda Range Road Upgrade Project. Commonwealth Environment Research Facilities - Marine and Tropical Sciences Research Facility. School of Earth and Environmental Sciences, James Cook University, Cairns.

HASENACK, H. (coord.). 2008. Diagnóstico Ambiental de Porto Alegre: geologia, solos, drenagem, vegetação/ocupação e paisagem. Secretaria Minicipal do Meio Ambiente, Porto Alegre, 84p.

HUIJSER, M.P., WAGNER, M.E., HARDY, A., CLEVENGER, A.P. \& FULLER, J.A. 2007. Animal-vehicle collision data collection throughout the United States and Canada. In Proceedings of the 2007 International Conference on Ecology and Transportation (C.L. Irwin, D.Nelson \& K.P. McDermott, eds.). Center for Transportation and the Environment, North Carolina State University, p.387-391.

INSTITUTO BRASILEIRO DE GEOGRAFIAE ESTATÍSTICA-IBGE. 2010. http://www.ibge.gov.br. (último acesso em: 30/07/2012).

LAURENCE, W.F., GOOSEM, M. \& LAURANCE, S.G.W. 2009. Impacts of roads and linear clearings on tropical forests. Trends Ecol. Evol. 24(12):659-669. http://dx.doi.org/10.1016/j.tree.2009.06.009
LEHMAN, R.N., KENNEDY, P.L. \& SAVIDGE, J.A. 2007. The state of the art in raptor electrocution research: A global review. Biol. Conserv. 136:159174. http://dx.doi.org/10.1016/j.biocon.2006.09.015

LOKSCHIN, L.X., PRINTES, R.C., CABRAL, J.N.H. \& BUSS, G. 2007. Power lines and howler's conservation (Alouatta guariba clamitans; Cabrera, 1940) in Porto Alegre, Rio Grande do Sul, Brazil. Netrop. Primates 14(2):76-80. http://dx.doi.org/10.1896/044.014.0206

LYON, J. \& HORWICH, R.H. 1996. Modification of tropical forest patches for wildlife protection and community conservation in Belize. In Forest Patches in Tropical Landscapes (Schelhas, J. \& Greenberg, R., eds.). Island Press, Washington, p.205-230.

MALO, J.E., HERVÁS, I., HERRANZ, J., MATA, C. \& SUÁREZ, F. 2006. How many days to monitor a wildlife passage? Species detection patterns and the estimation of the vertebrate fauna using crossing structures at a motorway. In Proceedings of the 2005 International Conference on Ecology and Transportation (C.L. Irwin, D. Nelson \& K.P. McDermott, eds.). Center for Transportation and the Environment, North Carolina State University, p.406-413.

MARQUES, A.A. 2003. Primatas. In Livro Vermelho da Fauna Ameaçada de Extinção no Estado do Rio Grande do Sul (C. Fontana, G. Bencke, \& R.E. Reis, eds). Porto Alegre, Edipucrs, p.499-506.

MENEGAT, R. (ed.). 1998. Atlas Ambiental de Porto Alegre. UFRGS/PMPA/ INPE, Porto Alegre.

OLIVEIRA-FILHO, A.T. \& FONTES, M.A.L. 2000. Patterns of Floristic Differentiation among Atlantic Forests in Southeastern Brazil and the Influence of Climate. Biotropica 32(4b):793-810. http://dx.doi. org/10.1111/j.1744-7429.2000.tb00619.x

PRINTES, R.C. 1999. The Lami biological reserve, Rio Grande do Sul, Brazil and the danger of power lines to howlers in urban reserves. Neotrop. Primates 7(4):135-136.

PRINTES, R.C. (org.). 2002. Plano de Manejo Participativo da Reserva Biológica do Lami. SMAM, Porto Alegre.

SOANES, K. \& VAN DER REE, R. 2009. Arboreal mammals use an aerial rope bridge to cross a major highway. In International Conference on Ecology and Transportation, Duluth, Minnesota, USA. (P.J. Wagner, D. Nelson \& E. Murray, eds.). Center for Transportation and the Environment, North Carolina State University, Raleigh, p.441-451.

TAYLOR, B.D. \& GOLDINGAY, R.L. 2010. Roads and wildlife: impacts, mitigation and implications for wildlife management in Australia. Wildlife Res. 37:320-331. http://dx.doi.org/10.1071/WR09171

TAYLOR, B.D. \& GOLDINGAY, R.L. 2012. Facilitated movement over major roads is required to minimise extinction risk in an urban metapopulation of a gliding mammal. Wildlife Res. 39:685-695.

VALLADARES-PADUA, C., CULLEN JUNIOR, L. \& PADUA, S. 1995. A pole bridge to avoid primate road kills. Neotrop. Primates 3(1):13-15.

VAN DER REE, R., VAN DER GRIFT, E., GULLE, N., HOLLAND, K., MATA, C. \& SUAREZ, F. 2007. Overcoming the barrier effect of roads - how effective are mitigation strategies? An international review of the use and effectiveness of underpasses and overpasses designed to increase the permeability of roads for wildlife. In Proceedings of the 2007 International Conference on Ecology and Transportation (C.L. Irwin, D. Nelson \& K.P. McDermott, eds.). Center for Transportation and Environment, North Carolina State University, Raleigh, North Carolina, p.423-431.

WESTON, N.G. 2003. The provision of canopy bridges to reduce the effects of linear barriers on arboreal mammals in the Wet Tropics of northeastern Queensland. Master Thesis in The School of Tropical Environmental Studies and Geography and the Centre for Tropical Urban \& Regional Planning at James Cook University of North Queensland, 228p.

Weston, N.G., GOOSEM, M., MARSH, H., COHEN, M. \& WILSON, R. 2011. Using canopy bridges to link habitat for arboreal mammals: successful trials in the Wet Tropics of Queensland. Aust. Mammal. 33:93-105. http://dx.doi.org/10.1071/AM11003 